\title{
Treatment Vehicle Amount
}

National Cancer Institute

\section{Source}

National Cancer Institute. Treatment Vehicle Amount. NCI Thesaurus. Code C82553.

The quantity of a treatment vehicle. 